\title{
Determination of Fertility Rate between Districts/Cities in Riau Province
}

\author{
Muhammad Hidayat $^{1}$, Dewi Mahrani Rangkuty ${ }^{2}$, Baby Syafitri ${ }^{3}$ \\ 1,2,3 Department of Economics \\ ${ }^{1,3}$ Universitas Muhammadiyah Riau, Pekanbaru City, Riau, Indonesia \\ ${ }^{2}$ Universitas Pembangunan Panca Budi, Medan City, North Sumatera, Indonesia \\ Corresponding Author: Dewi Mahrani Rangkuty
}

DOI: https://doi.org/10.52403/ijrr.20220182

\begin{abstract}
This study aims to identify and determine the effect of purchasing power, female labor force participation rates (wLFPR), and contraception against fertility between regency/municipalities in Riau Province. The analytical tool used is panel data regression using the Random Effect Model. Based on the data processing results, the highest fertility was in Rokan Hilir Regency, and the lowest was Siak Regency. Econometric results show that purchasing power and contraceptives positively and significantly affect fertility. In contrast, the female labor force participation rate has a negative and significant impact on fertility in the regency/municipality of Riau Province.
\end{abstract}

Keywords: Contraceptives; Female Labor; Fertility; Panel Data; Purchasing Power

\section{INTRODUCTION}

Population growth is one of the significant economic development problems facing most developing countries such as Indonesia. The amount of population growth can be a burden for developing countries, and a large population can result in uneven distribution of people in a region. Uneven population growth will hinder economic growth and development in the province or developing country.

Based on the projection of Indonesia's population by regency/city in 2010-2020, in 2015, the people of Riau
Province are estimated to amount to $6,344,402$ people with households as many as 1,374,024 homes with an average number of household members in Riau Province as many as four people per household. The distribution of population in 2015 by Regency / City in Riau Province shows that the most significant population distribution is in Pekanbaru City as the provincial capital of $16.36 \%$ of the entire population of Riau or as many as $1,038,188$ people, while the minor population distribution in Riau Province is in Meranti Islands Regency as many as 182,152 people (Riau Central Statistics Agency, 2016).

Areas with large populations will face problems in the economic and social fields such as increasing the number of unemployed because it is not balanced with the provision of jobs, issues of land needs for settlement, and inadequate access to educational and health facilities social, economic problems.

According to the Central Statistic Agency of Riau Province, the population of districts and cities increases every year, affecting the number of residents in Riau Province. In 2011-2015 the population of Riau Province amounted from 5,538,367 people to $6,344,402$ people. Furthermore, the average percentage of population growth is presented in figure 1. 


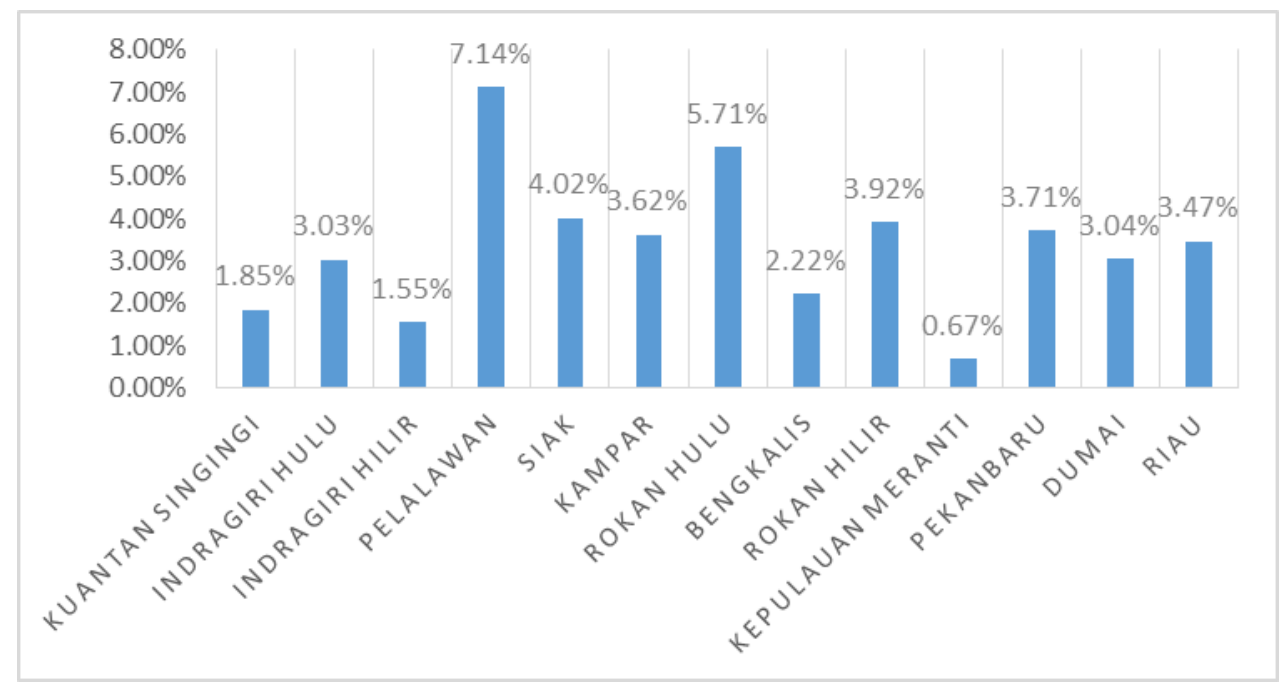

Figure 1. Average District/City Population Growth, 2011-2015 (\%)

Source: Statistic of Riau

Based on Figure 1, the average population growth of Riau Province during 2011-2015 amounted to 3.47 percent, and the highest population growth occurred in Pelalawan Regency at 7.14 percent and the lowest in Meranti Islands Regency at 0.67 percent. Meanwhile, the population density of Riau Province in 2012 reached 68 people per $\mathrm{km} 2$, the population density of Riau Province continued to increase until 2016 reached 75 people per $\mathrm{km} 2$.

The increase in population will have an impact on population problems. One of the problems faced with the increasing population is the uneven distribution of the people, which impacts the growing population density. The largest population in Riau Province is in Pekanbaru City. The rest is spread outside Pekanbaru city. This certainly affects the population density in Pekanbaru City.

Factors that affect the population of a region or country include fertility (birth), mortality (death), and migration. This study that will be discussed is one of the factors affecting the number of residents in Riau Province, namely fertility (birth). Fertility (labor) is one component of population growth that increases the population. The number of fertility (births) in Riau Province is volatile and supplements every year. Based on BPS data, the number of babies born alive in Riau Province in 2011 amounted to 72,299 people and increased steadily until 2015 to 132,411 people.

The number of fertility in an area will affect the number of residents in the future. The increasing number of fertility in the present will cause the number of people in the future will increase, the growing number of residents that improved facilities and infrastructure do not follow to support the welfare of people's lives better so that it will result in a lack of land for settlement, increasing numbers of unemployment, lack of educational and health facilities, and so on. One way that the population can be controlled is by supervising or controlling fertility (birth) levels.

Research conducted by Hanifah (2012) entitled the influence of income levels, education levels, life expectancy, women's first marriage age, and the use of contraceptives in women against fertility in East Java in the period 2002-2009 resulted in that income level, education level, life expectancy, women's first marriage age, and the use of contraceptives in women significantly affect fertility in East Java.

Mirah's research (2013) discusses fertility results in that family income, wife education, husband education, working hours, first marriage age, and prolonged contraceptives simultaneously affect fertility in Tegal Besar Village Kaliwates Subdistrict. 
Furthermore, Nasir's research (2012) provided significant factors are residence, working status, household chief tribe, contraceptive use, income, first marriage age, length of the marriage, and the number of children who died affecting fertility/birth Aceh Province.

The results of the Sham study (2016) stated that the factors of education, the age of first marriage, income, and working hours of respondents negatively and significantly affect the fertility of female workers in Ujung Bulu District Bulukumba Regency.

Ismail \& Maimunah's research (2016) provides results that family income, education level, and first marriage age have a negative and significant influence on fertility, while the number of family members has a positive and significant effect on fertility in Tanjung Raya Village, Bandar Lampung Peace District.

Meanwhile, the study results Marlina, Normelani, \& Hastuti (2017) gave the effects that the main significant factor is the age of the first marriage of the wife. In line with the background and previous research, the purpose of this study is as follows: (1) Know the influence of purchasing power on fertility between regions in Riau Province. (2) Know the impact of women's labor force participation rates on inter-regional fertility in Riau Province. (3) Know the impact of contraceptive use on fertility between regions in Riau Province.

\section{METHODS}

Research methods are the part that explains the steps taken in research. The explanation should be brief so that the reader can evaluate the suitability of the validity results. It is highly recommended to establish formulas and equations of analytical models.

This study uses secondary data from 2011-2015, obtained from various reports and compilations of data and other forms of publication, such as from the Central Statistics Agency, Bank Indonesia, and the
District Development Planning Agency in Riau Province.

\section{Operational Definition}

1) Fertility $(F)$ is the number of children born to a woman in Riau Province measured by the number born alive during the reproductive period (soul).

2) Purchasing power (DB) is the ability of a person, family, or community to obtain goods/services to meet life's needs.

3) The female labor force participation rate (wLFPR) is an employment indicator that provides an overview of the economically active female population in daily activities, referring to a time in the survey period.

4) The use of contraceptives (AK) is a way or method that aims to prevent conception so that pregnancy does not occur.

\section{Data Analysis Method}

Regression panel data is used to analyze factors that affect fertility between districts/cities in Riau Province. Functions formed such as regression equations with fertility between districts/cities are allegedly influenced by purchasing power variables (DB), women's labor force participation rates (wLFPR), and contraceptives (AK) of each district/city. The variables with the most significant regression coefficient value are considered to have an essential role in influencing the ups and downs of fertility in Riau Province.

The common forms of the equation are:

Fertility $=\{P P, w L F P R, C t r\}$

Linear equations of panel data regression models can be formulated in the following models:

Fertility $_{i t}=\alpha_{i t}+\beta_{1} P P_{i t}+\beta_{2} w L F P R_{i t}+\beta_{3}$ Ctr $_{i t}+\varepsilon_{i t}$

Fertility $=$ birth rate (Soul); $\mathrm{PP}=$ Purchasing Power (Thousand Rp); wLFPR = Women's Labor Force Participation Rate $(\%)$; Ctr = Contraceptives $(\%) ; \mathrm{i}=$ Riau Provincial 
Regency; $\mathrm{t}=$ time (2011-2015); $\alpha=$ Constant; $\varepsilon=$ Error Term

\section{Panel Data Analysis}

Panel (pooled data) combines crosssection and series data. In other words, panel data is data from the same number of individuals observed over some time. In this study, data that is balanced panel is used. Because the data was obtained from 10 districts surveyed within five years, 50 observations were obtained. The use of panel data is essentially a solution to the unavailability of time-series data that is long enough for the benefit of econometric analysis.

The use of panel data in regression has several advantages, including; 1) Estimates of panel data can indicate heterogeneity in each individual. 2) With panel data, the data is more informative and varied, thereby reducing collinearity between variables and increasing the degree of freedom and more efficiency. 3) Panel data studies are more satisfactory for determining dynamic changes than repeated cross-section studies. 4) Data panels can detect and measure effects that cannot be measured by time series or cross-section data. 5) Panel data helps analyze more complex behaviors. 6) Panel data can minimize the biases generated by individual aggregation due to the numerous data units (Baltagi, 2005).

\section{Panel Data Regression Estimation}

In the analysis of panel data models, three types of approaches are Pooled Least Square (PLS), Fixed Effect Model, and Random Effect Model. The three methods to the panel data model will be explained below:

1. Pooled Least Square (PLS), the method of approaching the smallest square is the same as the ordinary least square (OLS) process only the data used is not time series data alone or cross-section only but is a panel data (a mixture between time series and cross-section). As the name implies, this method used panel data and least squares, which minimizes the number of square errors. Minimizing honest errors because fair mistakes are most likely, if summed, will be worth zero. If the error is only summed up without being squared, then there is an "injustice" because the value of the error is significant, and the small is equalized. PLS is a simple approach, but the results are inadequate because each is treated as a stand-alone observation.

2. Fixed Effect Model (FEM), The problem that arises in using the Pooled Least Square method is the assumption that the interception and coefficient of each variable are the same in each district observed. The individuality of each cross-section unit can be taken into account by making other interceptions in each section. The fixed effect method added dummy variables to change the interception, but the different coefficients remain the same for each district observed. Based on the assumption of the residual variancecovariance matrix structure, in the fixed effects model, three estimation methods can be used, namely: 1) Ordinary Least Square (OLS / LSDV) if the residual variance-covariance matrix structure is assumed to be homoscedastic and there is no cross-sectional correlation. 2) Weighted Least Square (WLS) if the residual variance-covariance matrix structure is assumed to be heteroskedastic and there is no crosssectional correlation. 3) Seemingly Uncorrelated Regression (SUR), if the residual variance-covariance matrix structure is assumed to be heteroskedastic, there is a crosssectional correlation.

In contrast to fixed effects models, the specific effects of each individual $\alpha \_i$ are treated as part of a random error component that is not correlated with the observed explanatory variable (X_it). Such a model is called a random-effects model (REM). This model is often referred to as the error component model 
(ECM). The OLS method cannot obtain an efficient estimator for random-effects models. The proper method for estimating random effects models is Generalized Least Squares (GLS), assuming homoscedastic and no crosssectional correlation.

3. In contrast to fixed effects models, the specific effects of each individual $\alpha \_i$ treated as part of a random error component that is not correlated with the observed explanatory variable (X_it), such a model is called a random effects model (REM). This model is often referred to as the error component model (ECM). The OLS method cannot be used to obtain an efficient estimator for random effects models. The proper method for estimating random effects models is Generalized Least Squares (GLS) assuming homoscedastic and no cross-sectional correlation.

\section{Selection of Models in Data Processing}

Formally, there are three testing procedures that will be used, namely the $\mathrm{F}$ statistical test used to choose between pooled least square or fixed effects models; Lagrange Multiplier (LM) test used to choose between pooled least square model or random effects model; and the Hausman test used to choose between fixed effects models or random effects models (Gujarati, 2004; Verbeek, 2012).

\section{Hausman Test}

The Hausman test is a statistical test as a basis for consideration in choosing whether to use FEM or REM. The Hausman test is performed with the following hypotheses: $\mathrm{H}_{0}:$ REM and $\mathrm{H}_{1}:$ FEM. As the basis for $\mathrm{H}_{0}$ rejection, Hausman Statistics is used and compares it with Chi-Square. If the $\mathrm{m}$ value of the test result is greater than $\mathrm{X}^{2}$ Tabel, or the Hausman Test value is greater than the real level, then there is not enough evidence to receive $\mathrm{H}_{0}$. So that the model used is fixed effect, and vice versa (Widarjono, 2013).

\section{Hypothesis}

Before hypothesis testing (Test $\mathrm{F}$, Test $\mathrm{T}$, and $\mathrm{R}^{2}$ ), the model is first tested to meet the requirements of BLUE (Best Linear Unbiased Estimator) which is tested with classical assumption tests, namely autokeration tests, multicollinearity tests and heteroskesdastosity tests (Widarjono, 2013).

\section{RESULT AND DISCUSSION 1) Hausman Test}

The Hausman test aims to choose whether using the fixed effect or random effect method is best to use. Assuming the hypothesis $\mathrm{H}_{0}$ : is a random effect method and $\mathrm{H}_{1}$ : is a fixed effect method.

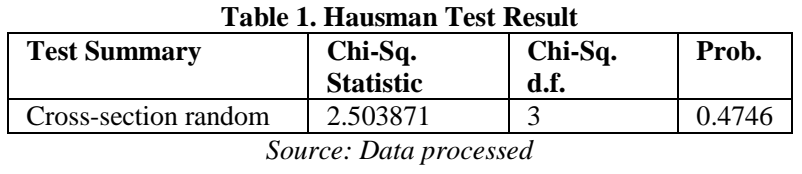

Based on the results of the Hausman test analysis above, the chi-square value of 2.503871 with a probability $=0.4746>0.05$ was to accept $\mathrm{H}_{0}$ and reject $\mathrm{H}_{1}$. So based on the Hausman test the right model to analyze fertility determinants above is the model random effect rather than the fixed effect model.

\section{2) Random Effect Model (REM)}

Tabel 2. The Summary of Data Panel Regression
\begin{tabular}{|l|l|l|l|l|}
\hline Variable & Coefficient & Std. Error & t-Statistic & Prob. \\
\hline C & 3056.419 & 3082.049 & 0.991684 & 0.3256 \\
\hline PP? & 1300.933 & 465.6229 & 2.793962 & 0.0071 \\
\hline wLFPR? & -233.6122 & 92.04996 & -2.537885 & 0.0140 \\
\hline Ctr? & 0.051754 & 0.012853 & 4.026593 & 0.0002 \\
\hline R-squared & 0.405754 & \multicolumn{4}{l}{} \\
\hline Adjusted R-squared & 0.373919 & & & \\
\hline F-statistic & 12.74569 & & & \\
\hline Prob(F-statistic) & 0.000002 & & & \\
\hline Durbin-Watson stat & 1.49202 & & & \\
\hline
\end{tabular}


After selecting the model, to find out the amount of influence of purchasing power, the participation rate of the women's labor force (wLFPR), and the use of contraceptives to fertility between districts / cities in Riau Province used regression analysis of panel data with random effect model.

In the output results using random effect models occur autocorrelation and also heteroscedasticity, because each panel data is assumed to tend to contain heteroscedasticity because it consists of many cross sections and to a significant degree between variables greater than alpha 0.05 so that to overcome the problem is used the white cross section method on the panel data. By using the white cross section method on the random effect model, the classic assumption test on the panel data is eliminated. Based on the results of the study obtained the regression equation line as follows:

Fertility $_{\text {it }}=3056,419+1300,933$ PB $-233,6122$ wLPR $+0,051754 \mathrm{Ctr}$

The results of the regression above state that fertility amounted to 3,056 people assuming the purchasing power of the community, women's wLFPR, and the use of contraceptives is considered constant or zero. Furthermore, purchasing power and contraceptive use were positively and statistically significant to fertility. Meanwhile, women's wLFPR was negative and statistically significant to fertility.

Based on the Table, the f-statistical value of $12.74569>2.76$ at the F-table and the probability value of 0.000002 is less than the alpha value of 0.05 . This means at a significant level of $95 \%$ declaring $\mathrm{H}_{0}$ rejected and $\mathrm{H}_{1}$ accepted. Thus it can be concluded that purchasing power factors, women's wLFPR, and contraceptive use have a significant effect together on fertility. Furthermore, for the determination coefficient test $\left(\mathrm{R}^{2}\right)$ obtained, the value of $\mathrm{R}^{2}$ of 0.405754 shows that $40.58 \%$ of purchasing power, the participation rate of the female labor force, and the use of contraceptives affect fertility in Riau regency/city. The remaining $59.42 \%$ were affected by other factors outside of the study.

\section{Influence of People's Purchasing Power on Fertility}

The regression coefficient value of the community purchasing power panel data is 1,300,933 meaning that if there is an increase in people's purchasing power by one unit it will increase the number of fertility by 1,301 people.

The t-statistical value of 2.793962 for people's purchasing power and the probability value of $0.0071<0.05$ significant level, this means that at a significant level $95 \%$ stated $\mathrm{H} 0$ was rejected and $\mathrm{H} 1$ accepted. Thus it can be concluded that the purchasing power factor of the community significantly affects fertility.

Based on the results of the study, it can be interpreted that if there is an increase in people's purchasing power means that the level of community welfare also improves, then the public interest in adding children will occur because parents assume they can care for and raise children well. In accordance with the theory of children as normal goods, if income rises will result in the desire to have children increase. In other words, there is a positive relationship between family income levels and fertility. This seems to conclude that the child is also an inferior or normal item.

According to Leibenstein (1957), having children can be seen from two economic aspects, namely in terms of utility and costs that must be incurred to raise and care for children. The usefulness (utility) of children is in providing satisfaction to parents, can provide economic transfer (e.g. providing remittances to parents in times of need), or can help in production activities such as helping to cultivate agricultural land. Children can also be a source that can help parents' lives in the future (investments). Meanwhile, the need to raise children is the cost of ownership of the child (Adioetomo et al. 2010). 
The results of this study are not in line with mirah research (2013); Ismail \& Maimunah (2016); Sham (2016); Sinaga et al. (2017) explain that income has a negative and significant relationship.

\section{Influence of Women's Labor Force Participation Rate (wLFPR) on Fertility}

The regression coefficient of women's wLFPR panel data is negative 233.6122 meaning that if there is an increase in the percentage rate of the female workforce by 1 percent it will reduce the number of fertility by 234 people. The tstatistical value of negative 2.537885 for the female labor force participation rate and the probability value of $0.0140<0.05$ significant level, this means that at a significant level $95 \%$ stated $\mathrm{H} 0$ was rejected and $\mathrm{H} 1$ accepted. Thus it can be concluded that the factor of the participation rate of the female labor force significantly affects fertility.

Based on the results of research that the number of women who work negatively affect fertility. Women who only take care of the household tend to have more children than working women. The number of women who work will cause fertility to decrease because women who work less time at home to take care of children so that the desire to have children is also reduced.

The results of this study, in line with Nasir's research (2012) the high value of the category of married women / ever married worked likely because the woman wants to earn income, to help the household economy.

Increased education for women and increased opportunities for women to work led to increased participation in the female labor force. The increasingly open employment, causing many women to jump into the job market. This also causes delays in the first marriage age. Women who only take care of the household tend to have more children while working women have fewer children (Adioetomo et al. 2010).

\section{Effect of Contraceptive Use on Fertility}

The regression coefficient value of the contraceptive use panel data is 0.051754 meaning that if there is an increase in the percentage of contraceptive use by 100 percent it will increase the number of fertility by 5 people. The t-statistical value of 4.026593 for contraceptive use and the probability value of $0.0002<0.05$ is significant, this means that at a significant level $95 \%$ stated $\mathrm{H} 0$ was rejected and $\mathrm{H} 1$ accepted. Thus it can be concluded that the factor of contraceptive use has a significant effect on fertility.

These results are not in line with Mirah's research (2013); Nasir (2012) the use of contraceptives is negatively associated with fertility, seen with a high awareness of using contraceptives in married women's households that is one way to limit the number of births in households.

In this study, the increase in married women who use contraceptives is not great effect on fertility continues to increase fertility rates in riau province. This happens due to a lack of understanding of the use of contraceptives in couples who use contraceptives. Judging from the various types of contraception tools have not guaranteed the effectiveness of their use, the lack of understanding and public education of the use of good and correct contraceptives also causes no effect on their use.

\section{CONCLUSION}

Based on the results of research with the Random Effect Model of the White Cross Section method that factors that affect fertility in Riau Regency / City can be concluded as follows: (1) People's purchasing power has a significantly positive effect on fertility; (2) The participation rate of the female labor force negatively and significantly affects fertility; (3) The use of contraceptives has a positive and statistically significant effect on fertility; (4) Purchasing power, women's wLFPR, and simultaneous use of contraceptives affect fertility with a 
probability value of 0.000002 less than the alpha value of 0.05 .

Based on the results of the study and conclusions, researchers provide the following advice: 1) It is expected that the district/city government of Riau Province to improve the existing Family Planning program to reduce or reduce the rate of births by extension or education of birth control programs for married couples; 2) It is expected for the community, especially married couples to be able further to improve the understanding of the importance of planning births, and prioritize the quality of children towards education and child health rather than prioritizing the number of children.

\section{Acknowledgement: None}

\section{Conflict of Interest: None}

\section{Source of Funding: None}

\section{REFERENCES}

1. Badan Pusat Statistik Riau. (2016). Riau Dalam Angka. Pekanbaru: Badan Pusat Statistik Provinsi Riau.

2. Baltagi, B. H. (2005). Economic Analysis of Panel Data (3rd ed.). Chichester, United Kingdom: John Willey \& Sons.

3. Gujarati, D. N. (2004). Basic Econometric (4th ed.). New York: Mc.Graw Hill companies.

4. Hanifah, S. (2012). Pengaruh Tingkat Pendapatan, Tingkat Pendidikan, Tingkat Harapan Hidup, Usia Kawin Pertama Wanita, dan Pemakaian Alat Kontrasepsi Pada Wanita Terhadap Fertilitas di Jawa Timur. Periode 2002-2009 (Universitas Airlangga). Retrieved from http://repository.unair.ac.id/1480/

5. Ismail, A. W., \& Maimunah, E. (2016). Faktor yang mempengaruhi fertilitas di Kelurahan Tanjung Raya Kecamatan Kedamaian Kota Bandar Lampung. Jurnal
Ekonomi Pembangunan (JEP), 5(3), 273288. Retrieved from http://repository.lppm.unila.ac.id/2120/1/jur nal emi maimunah november 2016.pdf

6. Marlina, S., Normelani, E., \& Hastuti, K. P. (2017). Faktor-Faktor yang Mempengaruhi Fertilitas di Kelurahan Pekauman Kecamanatan Banjarmasin Selatan. JPG (Jurnal Pendidikan Geografi), 4(2). Retrieved from https://ppjp.ulm.ac.id/journal/index.php/jpg/ article/view/3031/2587

7. Mirah, S. C. (2013). Analisis Faktor Yang Mempengaruhi Fertilitas Pekerja Wanita di Kelurahan Tegal Besar Kecamatan Kaliwates Kabupaten Jember (Universitas Jember). Retrieved from http://repository.unej.ac.id/bitstream/handle/ 123456789/5706/Suvita Cahyaning Mirah 090810101116.pdf?sequence $=1$

8. Nasir, M. (2012). Analisis Faktor-Faktor Ekonomi dan Sosial yang Mempengaruhi Fertelitas di Provinsi Aceh. Jurnal Ekonomika Indonesia, 1(1). Retrieved from http://jurnal.pnl.ac.id/?p=1065

9. Syam, E. R. L. (2016). Analisis Faktor yang Mempengaruhi Fertilitas Tenaga Kerja Wanita di Kecamatan Ujung Bulu Kabupaten Bulukumba (UIN Alauddin Makasar). Retrieved from http://repositori.uin-alauddin.ac.id/4984/

10. Verbeek, M. (2012). A Guide to Modern Econometrics (4th ed.). John Wiley \& Sons.

11. Widarjono, A. (2013). Ekonometrika Pengantar dan Aplikasinya. Yogyakarta: UPP STIM YKPN.

12. World Bank. (2017). World Development Indicators 2018. https://doi.org/CC BY 3.0 IGO

How to cite this article: Muhammad Hidayat, Dewi Mahrani Rangkuty, Baby Syafitri. Determination of fertility rate between districts/cities in Riau province. International Journal of Research and Review. 2022; 9(1): 714-721. DOI: https://doi.org/10.52403/ijrr. 20220182 